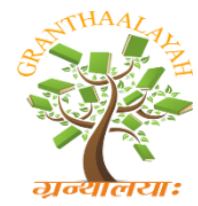

INTERNATIONAL JOURNAL OF RESEARCH GRANTHAALAYAH A knowledge Repository

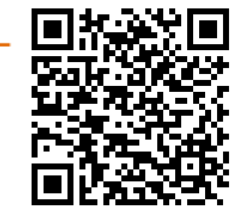

Management

\title{
TESTING THE DIRECT AND INDIRECT EFFECT OF CAPITAL STRUCTURE ON THE STOCK PRICE OF THE SELECT INDIAN PUBLIC SECTOR BANKS
}

\author{
Dr.M.S.Ramaratnam ${ }^{* 1}$, Dr.R.Jayaraman ${ }^{2}$ \\ ${ }^{*}$ Head of the Department, Department of Management Studies, Sri Chandrasekharendra \\ Saraswathi Viswa Mahavidyalaya (SCSVMV University), Enathur, Kanchipuram, Tamil Nadu - \\ 2 \\ 631561, India \\ Assistant Professor (Stage - II), Department of Management Studies, Sri Chandrasekharendra \\ Saraswathi Viswa Mahavidyalaya (SCSVMV University), Enathur, Kanchipuram \\ Tamil Nadu - 631561, India
}

DOI: https://doi.org/10.29121/granthaalayah.v5.i6.2017.2061

\begin{abstract}
Market Value of Share of a company is determined by various factors. So many studies were conducted in finding the determinants of share price. Some of the studies found that Capital Structure is a determinant of the market price of the share and some of the studies found that Earning per Share is a determinant of the market price of the share. Even some studies proved that Capital Structure is also determining the Earning per Share. With this ideology an attempt was made in this study by using Structural equation modeling to see how for the Capital Structure of the firm has got a direct and indirect effect over the Market value of share. Debt to Total Assets, Equity to Total Assets, Coverage Ratio, Earning per share and Market price of share of eleven Indian public sector banks were taken for the study for five years from March 2013 to March 2017.

Keywords: Structural Equation Modeling; Debt to Total Assets; Equity to Total Assets; Coverage Ratio; Earnings Per Share; Market Price of Share and Indian Public Sector Banks; Direct Effect and Indirect Effect.

Cite This Article: Dr.M.S.Ramaratnam, and Dr.R.Jayaraman. (2017). "TESTING THE DIRECT AND INDIRECT EFFECT OF CAPITAL STRUCTURE ON THE STOCK PRICE OF THE SELECT INDIAN PUBLIC SECTOR BANKS." International Journal of Research - Granthaalayah, 5(6), 495-501. https://doi.org/10.29121/granthaalayah.v5.i6.2017.2061.
\end{abstract}

\section{Introduction}

The share price of a firm is affected by various factors. Determination of share price is not an easy task. The share price movement is based on the firm's fundamentals (Key performance 
indicators of firm), Market efficiency, Macroeconomic Indicators (Gross Domestic Product, Oil Prices \& Inflation etc) and Perception of the Investors. Several studies have proven that share price of firms are explained by its capital structure. Earnings per Share are also determining the market price of the share. The Earnings arrived by a firm after deducting the depreciation, interest and Income tax is otherwise called as Profit after Tax. The Profit after Tax of a firm is considered as the Earnings available for the share holders particularly equity share holders. Every business unit is putting its efforts to maximize the profit after tax to satisfy its shareholders. To find the earnings per share, the profit after tax is to be divided by the total number of shares outstanding. Higher the level of profit after tax leads to hike in the earnings per share. For parking the funds in equity, the investors will always look after the Earnings per Share. Earnings per Share is one of the investor ratios. Even some studies proved that Capital Structure is also determining the Earning per Share. With this ideology an attempt was made in this study by using Structural equation modeling to see how for the Capital Structure of the firm has got a direct and indirect effect over the Market value of share Debt to Total Assets, Equity to Total Assets, Coverage Ratio, Earning per share and Market price of share of eleven Indian public sector banks were taken for the study for five years from March 2013 to March 2017.

\section{Review of Literature}

John C. Groth, Ronald C. Anderson, (1997) studied the capital structure from the perspective of the managers. From their study they revealed several practical strategies to enhance the value of the firm through capital structure.

Raheel Safdar, Chen Yan, (2016) made an attempt to find the impact of cost of capital on the share price movement. From their study they revealed that the cost of capital is impacting the market value of share.

George Athanassakos, (2007) studied share price movement of companies adopting value based management. The result of the study revealed that firms which concentrate on Economic Value Addition will be able to increase its share price performance.

Cécile Carpentier, (2006) studied in the title "The valuation effects of long-term changes in capital structure". In the study the researcher tried to look after the impact of changes in the capital structure in the value of the firm

Athanasios G. Noulas, Georgios Genimakis, (2014) surveyed the CFO'S of Greek listed companies. From the survey they revealed how the CFO'S of Greek listed companies make decisions in terms of capital structure.

John Consler, Greg M. Lepak, Susan F. Havranek, (2011) studied the relative power of cash flow per share and earnings per share in determining the dividends of firms. In their study they found that the influence of cash flow per share is at the higher side on dividends than EPS.

Mohammed Ibrahim Obeidat, (2009) studied the impact of Earnings per Share (EPS), Dividends per Share (DPS), and Book Value per Share (BVPS) on stock market prices in Abu 
Dhabi Securities Market. From the study it was found that there was a significant effect of EPS and BVPS on stock market price in the Abu Dhabi Securities Market

Scott Pirie, Malcolm Smith, (2003) made an attempt to see how the accounting influencing the share prices of various firms

J.C.Y. How, C.S. Teo, H.Y. Izan, (1992) witnessed the combined effect of Dividend announcements and accounting earnings on share price

J. Dahyaa, A.A. Lonie, D.M. Power, (2000) made an attempt to view how changes in the top management (Board of directors) will influence both the market value of share and accounting performance (EPS).

\section{Research Methodology}

The study relied upon the secondary data. Debt to Total Assets, Equity to Total Assets, Coverage Ratio, Earnings per Share and Market share price of eleven Indian public sector banks were taken for the study for five years from March 2013 to March 2017. Structural Equation Modeling (SEM) is used in this study.

\section{Hypothesis}

The following hypothesis were framed for the study

H0: There is no direct effect of capital structure on the share price

$\mathrm{H} 0$ : There is no indirect effect of capital structure on the share price

\section{Data Analysis}

\section{Testing the Direct effect (without mediation)}

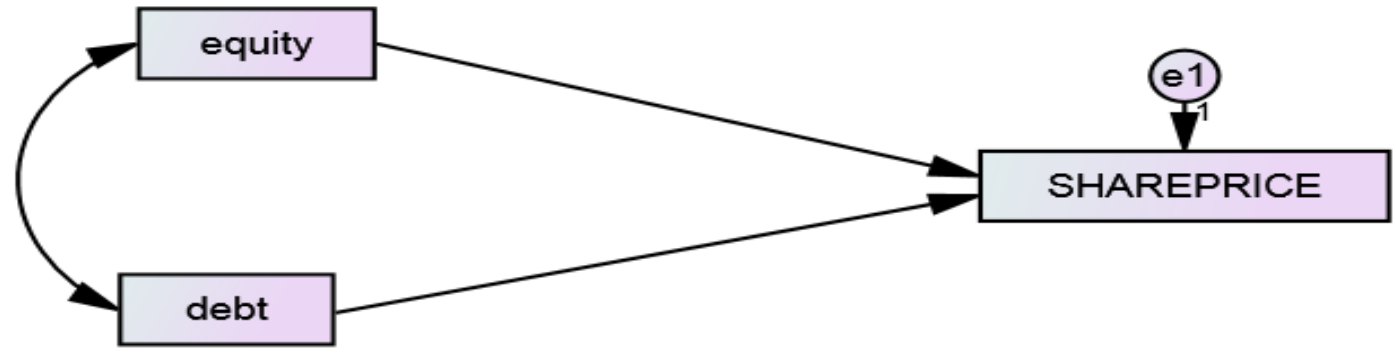


Testing the Direct effect (with standardized estimates)

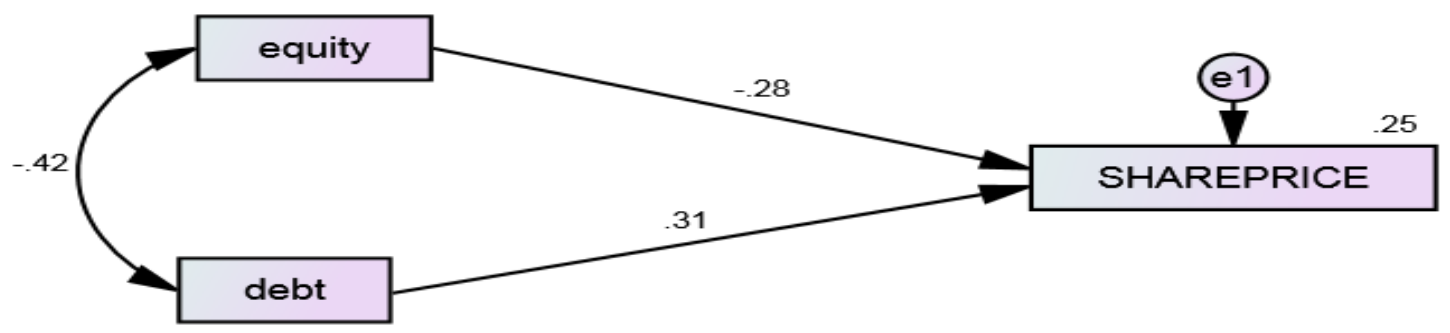

Table 1: Regression Weights: (Group number 1 - Default model)

\begin{tabular}{|l|l|l|l|l|l|l|l|}
\hline & & & Estimate & S.E. & C.R. & P & Label \\
\hline SHAREPRICE & $<---$ & equity & -62111.383 & 28775.518 & -2.158 & .031 & \\
\hline SHAREPRICE & $<---$ & debt & 4885.805 & 2048.298 & 2.385 & .017 & \\
\hline
\end{tabular}

Source: Computed data

Testing the Direct effect (with mediation) and indirect effect

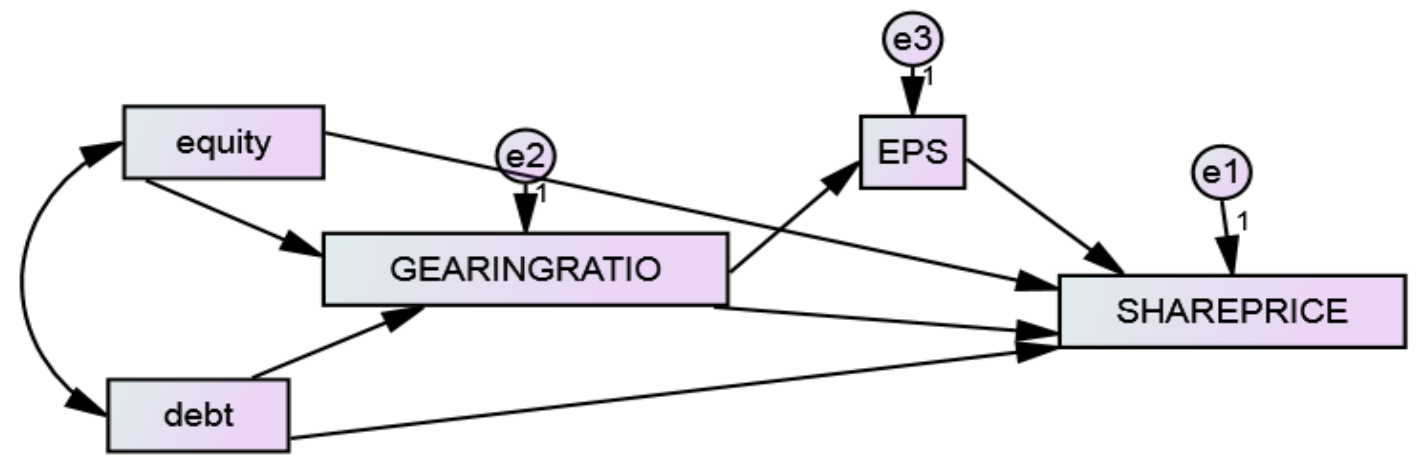

Testing the Direct effect (with mediation) and indirect effect (with standardized estimates)

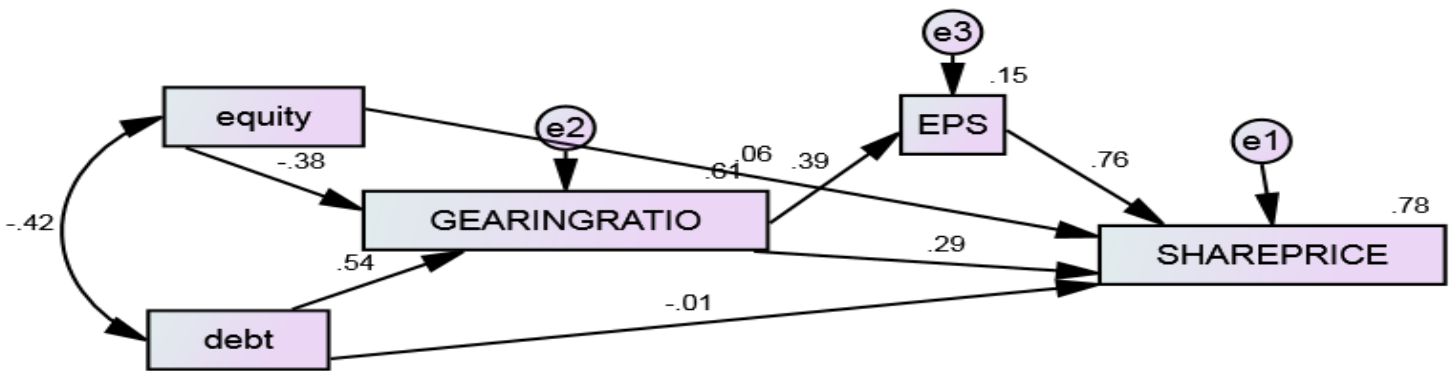




\begin{tabular}{|l|l|l|l|l|}
\hline \multicolumn{5}{|c|}{ Table 2: Standardized Direct Effects (Group number 1 - Default model) } \\
\hline & debt & equity & GEARINGRATIO & EPS \\
\hline GEARINGRATIO & 0.542 & -0.378 & 0 & 0 \\
\hline EPS & 0 & 0 & 0.388 & 0 \\
\hline SHAREPRICE & -0.005 & 0.056 & 0.285 & 0.758 \\
\hline
\end{tabular}

Source: Computed data

\begin{tabular}{|l|l|l|l|l|}
\hline \multicolumn{5}{|l|}{ Table 3: Standardized Direct Effects - Two Tailed Significance (BC) (Group number 1 - Default } \\
model)
\end{tabular}

Source: Computed data

Table 4: Standardized Indirect Effects (Group number 1 - Default model)

\begin{tabular}{|l|l|l|l|l|}
\hline & debt & equity & GEARINGRATIO & EPS \\
\hline GEARINGRATIO & .000 & .000 & .000 & .000 \\
\hline EPS & .210 & -.146 & .000 & .000 \\
\hline SHAREPRICE & .314 & -.219 & .294 & .000 \\
\hline
\end{tabular}

Source: Computed data

Table 5: Standardized Indirect Effects - Two Tailed Significance (BC) (Group number 1 -

Default model)

\begin{tabular}{|l|l|l|l|l|}
\hline & debt & equity & GEARINGRATIO & EPS \\
\hline GEARINGRATIO & $\ldots$ & $\ldots$ & $\ldots$ & $\ldots$ \\
\hline EPS & .016 & .020 & $\ldots$ & $\ldots$ \\
\hline SHAREPRICE & .026 & .026 & .016 & $\ldots$ \\
\hline
\end{tabular}

Source: Computed data

\section{Condition for Direct and Indirect effect}

\section{No Mediation}

- If Indirect is not significant

- Also if direct effect of IV on Med is insignificant or if direct effect from Med to Y is insignificant

\section{Indirect Effects}

- Both direct effects are not significant, but Indirect effect is significant

\section{Full Mediation}

- Given the direct effects were significant prior to adding the mediator

- If Indirect is significant and Direct (with med) is not significant

Partial Mediation

- If Direct (with med) \& Indirect are significant 


\section{Inference}

The inference of the above analysis is given in the tabular form (Table 6)

Table 6: Inference table

\begin{tabular}{|c|c|c|c|c|c|c|c|}
\hline \multirow[t]{2}{*}{ Hypothesis } & \multicolumn{2}{|c|}{$\begin{array}{l}\text { Direct Beta w/o } \\
\text { Med }\end{array}$} & \multicolumn{2}{|c|}{ Direct Beta w/Med } & \multicolumn{2}{|c|}{ Indirect Beta } & \multirow{2}{*}{$\begin{array}{l}\text { Mediation } \\
\text { type } \\
\text { observed }\end{array}$} \\
\hline & Estimate & $\mathbf{P}$ & Estimate & $\mathbf{P}$ & Estimate & $\mathbf{P}$ & \\
\hline $\begin{array}{l}\text { Partial Med } \\
\text { Equity } \\
\text { coverage - EPS - } \\
\text { Share price }\end{array}$ & -0.28 & $\begin{array}{l}0.031 \\
\text { (Table } \\
1)\end{array}$ & $\begin{array}{l}0.056 \\
\text { (Table 2) }\end{array}$ & $\begin{array}{l}0.487 \\
\text { (Table } \\
3)\end{array}$ & $\begin{array}{l}-0.219 \\
(\text { Table 4) }\end{array}$ & $\begin{array}{l}0.026 \\
\text { (Table } \\
5)\end{array}$ & $\begin{array}{l}\text { Full } \\
\text { mediation }\end{array}$ \\
\hline $\begin{array}{l}\text { Partial Med } \\
\text { Debt - coverage } \\
\text { - EPS - Share } \\
\text { price }\end{array}$ & 0.31 & $\begin{array}{l}0.017 \\
\text { (Table } \\
1)\end{array}$ & $\begin{array}{l}-0.005 \\
\text { (Table 2) }\end{array}$ & $\begin{array}{l}0.975 \\
\text { (Table } \\
3)\end{array}$ & $\begin{array}{l}0.314 \\
\text { (Table 4) }\end{array}$ & $\begin{array}{l}0.026 \\
\text { (Table } \\
5)\end{array}$ & $\begin{array}{l}\text { Full } \\
\text { mediation }\end{array}$ \\
\hline
\end{tabular}

\section{Conclusion}

From the study it is observed that the direct effect without mediation and indirect effect are significant but the direct effect with mediation is significant. So it falls under the full mediation condition. The full mediation condition is applicable when the given the direct effects were significant prior to adding the mediator and the Indirect is significant and Direct (with med) is not significant. Hence it is proved that there is an indirect effect of capital structure on the share price with full mediation of coverage ratio and Earnings per share.

\section{References}

[1] John C. Groth, Ronald C. Anderson, (1997) "Capital structure: perspectives for managers", Management Decision, Vol. 35 Issue: 7, pp.552-561

[2] Raheel Safdar, Chen Yan, (2016) "Information risk, stock returns, and the cost of capital in China", China Finance Review International, Vol. 6 Issue: 1, pp.77-95

[3] George Athanassakos, (2007) "Value-based management, EVA and stock price performance in Canada", Management Decision, Vol. 45 Issue: 9, pp.1397-1411

[4] Cécile Carpentier, (2006) "The valuation effects of long-term changes in capital structure", International Journal of Managerial Finance, Vol. 2 Issue: 1, pp.4-18

[5] Athanasios G. Noulas, Georgios Genimakis, (2014) "How do CFOs make capital structure decisions? A survey of Greek listed companies", Studies in Economics and Finance, Vol. 31 Issue: 1 , pp.72-87

[6] John Consler, Greg M. Lepak, Susan F. Havranek, (2011) "Earnings per share versus cash flow per share as predictor of dividends per share", Managerial Finance, Vol. 37 Issue: 5, pp.482-488,

[7] Mohammed Ibrahim Obeidat, (2009) "The Internal Financial Determinants of Common Stock Market Price: Evidence from Abu Dhabi Securities Market", Journal of Economic and Administrative Sciences, Vol. 25 Issue: 1, pp.21-46

[8] Scott Pirie, Malcolm Smith, (2003) "Accounting earnings, book values and share prices in Malaysia", Asian Review of Accounting, Vol. 11 Issue: 2, pp.31-52 
[9] J.C.Y. How, C.S. Teo, H.Y. Izan, (1992) "The Interaction Effect of Earnings and Dividend Announcements on Share Price: Australian Evidence", Managerial Finance, Vol. 18 Issue: 1, pp.22-33

[10] J. Dahyaa, A.A. Lonie, D.M. Power, (2000) "Changes in corporate management: do they have an impact on share prices and company earnings?", Managerial Finance, Vol. 26 Issue: 9, pp.66-79.

*Corresponding author.

E-mail address: hellomsraman@gmail.com 